\title{
Improvement of anticorrosive performance of phosphate-based alkyd paints with suitable additives
}

\author{
G. Blustein, M. C. Deyá, R. Romagnoli, \\ A. R. Di Sarli, B. del Amo
}

(C) ACA and OCCA 2010

\begin{abstract}
The purpose of this investigation was focused on reducing the content of zinc phosphate in anticorrosive paints by means of the incorporation of low quantities of selected soluble corrosion inhibitors. The article describes the anticorrosive behavior of alkyd paints containing reduced levels of zinc phosphate, zinc oxide, and some soluble compounds used as additives (e.g., sodium polyphosphate, sodium phosphate, and sodium benzoate). Anticorrosive solventborne alkyd paints were formulated with a zinc phosphate content of $10 \%$ by volume $(\mathrm{v} / \mathrm{v})$ with respect to the total pigment concentration. In all cases, the $\mathrm{PVC} / \mathrm{CPVC}$ (pigment volume concentration/critical pigment volume concentration) ratio was 0.8. Experimental paints, applied on sandblasted SAE 1010 panels, were evaluated by accelerated tests (salt spray cabinet) and electrochemical measurements (electrochemical impedance spectroscopy, EIS). The results show that the additions of small amounts of soluble corrosion inhibitors to low content zinc phosphate paint formulations enhance their performance in a very remarkable way. Perhaps, the most outstanding feature is that the employment of soluble additives allowed the reduction of the zinc phosphate content with concomitant savings.
\end{abstract}

Keywords Anticorrosive paints, Phosphate pigments, Soluble additives, Electrochemical impedance spectroscopy

G. Blustein ( $₫)$, M. C. Deyá, R. Romagnoli,

A. R. Di Sarli, B. del Amo

CIDEPINT, Centro de Investigación y Desarrollo en

Tecnología de Pinturas (CICPBA-CONICET),

Calle 52 e/121 y 122, B1900AYB La Plata, Argentina

e-mail: pinturashigienicas@cidepint.gov.ar

\section{Introduction}

Corrosion protection of metals and the replacement of toxic compounds in paint formulations are the most important ambitions claimed in the field of paint technology. In this sense, the elimination of classical anticorrosive pigments (e.g., lead and chromate compounds) in paints is of great interest.

Many compounds have been suggested as possible replacements for chromates and lead compounds, but zinc phosphate and related substances became the leading substitutes for toxic inhibitors. Three generations of phosphates were introduced in the market, with zinc phosphate as the precursor. A second generation of phosphate pigments was developed by modifying zinc phosphate adding suitable cations, such as molybdenum or aluminum, or by reducing the particle size. The third generation is concerned with the substitution of the phosphate anion by the tripolyphosphate one. ${ }^{1-25}$

As a general rule, it can be stated that the protective action of zinc phosphate is due to the formation of an iron oxyhydroxides film on the steel substrate, which is non-expansive in nature. ${ }^{1,26}$ The polarization of cathodic areas by the precipitation of sparingly soluble salts, which strongly adhere to the surface, also contributes to metal passivation. ${ }^{2,26,27}$

Usually, the zinc phosphate load in high performance anticorrosive paints is $\sim 30 \% \mathrm{v} / \mathrm{v}$ of the total pigment content. ${ }^{6,9,10,23-26}$ As it will be discussed later, poorer results were obtained when lower zinc phosphate contents were employed. However, this content could be reduced following two different ways. Blends of zinc phosphates with other non-toxic corrosion inhibitors can be used to give similar or better anticorrosive performance and, simultaneously, to reduce the phosphate content. ${ }^{28}$ In this sense, zinc phosphate has been combined with borates and molybdates with improved results ${ }^{3,29}$ and, more recently, formulations 
containing phosphate/polyaniline and phosphate/ molybdenyl-modified zeolites were reported in the literature. ${ }^{30,31}$ The employment of suitable additives, particularly organic inhibitors, which often act synergistically, was also of great concern and it is reported in current literature. ${ }^{28-38}$ Zinc nitrophtalate, zinc benzoates, metallic sulfonates, phosphonic acids and their derivatives, amines salts of succinic acid, etc., were incorporated to paint formulations with success.

The incorporation of soluble compounds in anticorrosive formulations containing zinc phosphate to enhance their anticorrosive properties or to avoid the flash rusting process is documented in the literature. ${ }^{39-41}$ However, the soluble compounds content must be limited because their leaching by water penetrating the pores of the coating would greatly increase coating permeability with the concomitant loss of the protective properties of the paint. ${ }^{42-44}$ In brief, if soluble compounds are used at very low concentration (e.g., as additives), it is possible that the anticorrosive performance of paint system could be enhanced.

The purpose of this investigation was to reduce the zinc phosphate content, in alkyd paints, by means of the incorporation of low quantities of selected soluble corrosion inhibitors (e.g., sodium phosphate, sodium polyphosphate, and sodium benzoate). The inhibitive properties of these compounds were known from many years ago ${ }^{2,27,45-53}$ and they were utilized by the authors to precipitate certain anticorrosive pigments in the past. $^{22-25,54-57}$ We hypothesize that the incorporation of soluble corrosion inhibitor to the paints formulations would enhance their anticorrosive performance and this fact would allow reducing zinc phosphate content without impairing the coatings protective ability.

Anticorrosive alkyd paints containing low content of zinc phosphate, zinc oxide and the selected corrosion inhibitors were formulated and their performance was evaluated in the salt spray chamber and EIS.

The results showed that zinc phosphate content could be reduced with the addition of the soluble active compound, but the performance of the paint depends on the nature of the additives.

\section{Experimental section}

\section{Composition, manufacture, and application of paints}

The resin employed to formulate solventborne alkyd paints was a medium oil alkyd (50\% linseed oil, $30 \%$ $o$-phtalic anhydride, $8 \%$ pentaerythritol and glycerol, and $12 \%$ pentaerythritol resinate). The ${ }^{\circledR}$ ALKYPOL $352 / 50$ resin employed to carry out this research was provided by POLIDUR S.A. from Argentina. For all paints white spirit was used as solvent. The PVC/CPVC (pigment volume concentration/critical pigment volume concentration) relationship was 0.8 as suggested elsewhere. ${ }^{9,10}$

The anticorrosive pigment load was $10 \% \mathrm{v} / \mathrm{v}$ of the total pigment content and titanium dioxide, barium sulfate, and zinc oxide were incorporated to complete the pigment formula. All pigments were dispersed for $24 \mathrm{~h}$ in the vehicle, employing a ball mill, to achieve an acceptable dispersion degree.

Three soluble additives were selected to be incorporated to the previous formulation to enhance its anticorrosive properties. From now on, paints will be numbered according to the soluble additive employed in each case. Paint 1 contained sodium polyphosphate; paint 2 was formulated with sodium benzoate; sodium phosphate was the additive for paint 3 ; and paint 4 was the reference paint. In every case Merck ${ }^{\mathrm{TM}}$ reagents grade chemicals were used. The composition of the paint 4 could be seen in Table 1 . In order to elaborate the paints $1-3$, soluble additives, $2 \% \mathrm{v} / \mathrm{v}$, were incorporated to paint 4 and, then, dispersed during $1 \mathrm{~h}$.

Solventborne paints were chosen to assess the anticorrosive behavior of these additives because their behavior was very well documented for many years and the alkyd resin was selected because its use is widespread. The selected zinc phosphate content was low and it cannot ensure, by itself, an appropriate anticorrosive performance. It is also important to point out that this content is just one-third of that recommended in the literature for adequate protection. ${ }^{2,6,9,10}$

Prior to painting, SAE 1010 steel panels were sandblasted to Sa 2 1/2 (SIS 055900 ) and degreased with toluene. Then, paints were applied on steel panels $(15.0 \times 7.5 \times 0.2 \mathrm{~cm})$ by brushing to reach a dry-film thickness of $80 \pm 5 \mu \mathrm{m}$. Painted panels were kept indoors for 14 days before testing.

\section{Anticorrosive performance evaluation of paints through accelerated tests}

\section{Salt fog chamber}

For each type of paint, a set of three panels, coated only with the alkyd paint (without topcoats), was placed in the salt spray chamber according to ASTM B 117 specification (Table 2). ${ }^{58}$ Rusting and blistering degrees were evaluated in relation to ASTM standards, ${ }^{59,60}$ i.e., ASTM D-610 and ASTM D-714, respectively; as function of the exposure time.

Table 1: Composition of paint 4 as vol\%

\begin{tabular}{lccccc}
$\begin{array}{l}\text { Zinc } \\
\text { phosphate }\end{array}$ & $\begin{array}{c}\text { Titanium } \\
\text { dioxide }\end{array}$ & Barite & $\begin{array}{c}\text { Zinc } \\
\text { oxide }\end{array}$ & $\begin{array}{c}\text { Alkyd } \\
\text { resin }\end{array}$ & $\begin{array}{c}\text { White } \\
\text { spirit }\end{array}$ \\
\hline 2.2 & 4.3 & 7.9 & 7.9 & 49.3 & 28.4 \\
\hline
\end{tabular}


Table 2: Salt spray chamber test (ASTM B 117)

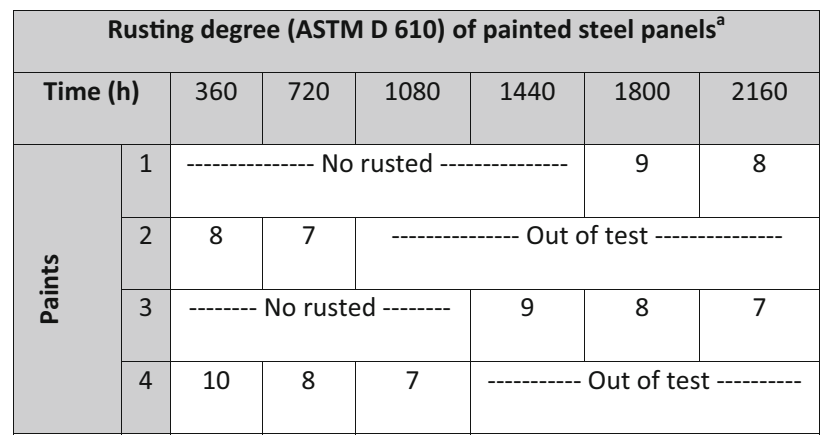

\begin{tabular}{|c|c|c|c|c|c|c|c|c|c|c|}
\hline \multicolumn{1}{|c|}{ Rusting degree (ASTM D 610) } \\
\hline Rust grade & 10 & 9 & 8 & 7 & 6 & 5 & 4 & 3 & 2 & 1 \\
\hline Rusted area (\%) & No rusted & 0.03 & 0.1 & 0.3 & 1 & 3 & 10 & 16 & 33 & 50 \\
\hline
\end{tabular}

\section{Electrochemical tests}

Impedance spectra of painted panels (frequency range $1 \times 10^{5} \mathrm{~Hz} \leq f \leq 1 \times 10^{-3} \mathrm{~Hz}$ ) were performed in the potentiostatic mode, at the corrosion potential $\left(E_{\text {corr }}\right)$. Measurements were carried out as a function of the exposure time in $3 \% \mathrm{NaCl}$ using the 1255 Solartron FRA and the 1286 Solartron EI. The amplitude of the applied AC voltage was $0.010 \mathrm{~V}$ peak to peak. Two acrylic tubes were attached to each coated panel (working electrode) with an epoxy adhesive; the geometric area exposed to the electrolyte was, in each cell, $15.9 \mathrm{~cm}^{2}$. A large area $\mathrm{Pt}-\mathrm{Rh}$ mesh of negligible impedance and saturated calomel (SCE) were employed as auxiliary and reference electrodes, respectively. The experimental impedance spectra were interpreted on the basis of equivalent electrical circuits using a suitable fitting procedure developed by Boukamp. ${ }^{61}$ The electrochemical experiments were carried out at laboratory temperature $\left(20 \pm 2^{\circ} \mathrm{C}\right)$, using a Faraday cage. Simultaneously, corrosion potential values were recorded as a function of immersion time.

\section{Results and discussion}

\section{Salt spray test}

As general rule, the performance of tested paints is regarded as satisfactory if they maintain a good qualification after $500 \mathrm{~h}$ of exposure. In this sense, all paints assessed in this work satisfied this criterion but there are significant differences between the tested paints which depend on the nature of the soluble compound employed (Table 2).

The anticorrosive performance of coatings containing sodium polyphosphate (paint 1) and sodium phosphate (paint 3), were clearly superior to that obtained with zinc phosphate alone (paint 4). The incorporation of sodium benzoate into the paint formulation had a deleterious effect on its anticorrosive behavior (paint 2).

Paint 1 obtained a qualification 8 after $2160 \mathrm{~h}$ of testing. Likewise, paint 3 behaved adequately but achieving qualification 7 in the same period of exposure. In contrast, paints 2 and 4 displayed a poorer behavior, getting a qualification 7 after 720 and $1080 \mathrm{~h}$, respectively. As it was expected, a very low zinc phosphate content could not provide a satisfactory anticorrosive behavior. ${ }^{9,10,26,62}$ In change, formulations containing $30 \% \mathrm{v} / \mathrm{v}$ of zinc phosphate, with respect to the total pigment content, were reported to undergo $1700 \mathrm{~h}$ of testing previous to failure. ${ }^{26} \mathrm{It}$ is clear that the incorporation of sodium phosphate and sodium tripolyphosphate to the paint formulation improved paints performance in such a way that lower zinc phosphate loadings gave a similar behavior to that obtained with $30 \%$ of zinc phosphate. Hence, it was concluded that the zinc phosphate content could be reduced only if the suitable anticorrosive additives (e.g., polyphosphate and phosphate anions) are added to the paint formulations.

It is well known that polyphosphate and phosphate anions restrained steel corrosion by generating a thin protective oxides film. ${ }^{2,27}$ It was thought that the presence of phosphate species, from soluble additives, in the pore solution, at the metal/paint interface, controlled the onset of the corrosion at the active sites of the base metal. An atypical behavior was detected when benzoate anion was employed as an anticorrosive additive. Benzoate ion hydrolyzes in water like any weak acids do, generating a fraction of benzoic acid in the pore solution of the coating. This fraction is higher at the anodic sites due to their acidic $\mathrm{pH}$ and this fact 
would prevent the formation of a protective layer of ferric benzoate. ${ }^{54}$ On the other hand, ferric phosphates could precipitate at lower $\mathrm{pH}$ values.

As a general rule, it can be said that alkyd paints did not blister during their time in the salt spray chamber, but that paint 2 blistered prematurely.

The good anticorrosive performance of paints 1 and 3 could be attributed to the inclusion of phosphate species in the anticorrosive paint formulation.

\section{Electrochemical impedance spectroscopy}

\section{Equivalent circuits}

Impedance spectra provide useful information concerning the evolution of both the organic coating protective properties and the kinetics of the underlying steel corrosion process, as a function of the immersion time in the selected electrolyte. The point of view adopted in this article was that of Amirudin and Thierry ${ }^{63}$ in the sense that visual observation of the spectra could not indicate the exact number of time constants involved in the degradation of the organic coating subjected to a corrosive environment. The number of these constants must be determined by data analysis rather than by visual observation of spectra. Fortunately, appropriate equivalent circuit has been proposed to describe the behavior of painted metals (Fig. 1); these circuits were discussed previously by several authors. ${ }^{63-68}$ Experimental impedance data are usually fitted with non-linear least squares algorithms, involving the transfer function derived from the equivalent circuit models, to obtain circuit parameters. ${ }^{69-72}$

The impedance of a high-quality, non-defective organic coating is that of a dielectric capacitor with a frequency dependence expressed by the following equation:

$$
Z c=-j / w C
$$

However, as the coating degrades, an in-phase component develops as a result of shorting the organic coating capacitance with a parallel resistor. This resistor represents the development of ionic conducting paths which may occur through microscopic pores or virtual pores defined by low cross-linking regions in the polymer with concomitant high ionic transport. ${ }^{72-77}$ Thus, $R_{\mathrm{s}}$ represents the electrolyte resistance between the reference and working (coated steel) electrodes, $R_{1}$ the resistance to the ionic flux through paths shortcircuiting the paint film, and $C_{1}$ the dielectric capacitance of the intact part of the same film (Fig. 1a).

Once the permeating and corrosion-inducing chemicals (water, oxygen, and ionic species) reach the electrochemically active areas of the substrate, particularly the bottom of the paint film pores, metallic corrosion takes place and its associated parameters, the double-layer capacitance $\left(C_{2}\right)$ and the charge transfer resistance $\left(R_{2}\right)$ can be obtained from the fitting
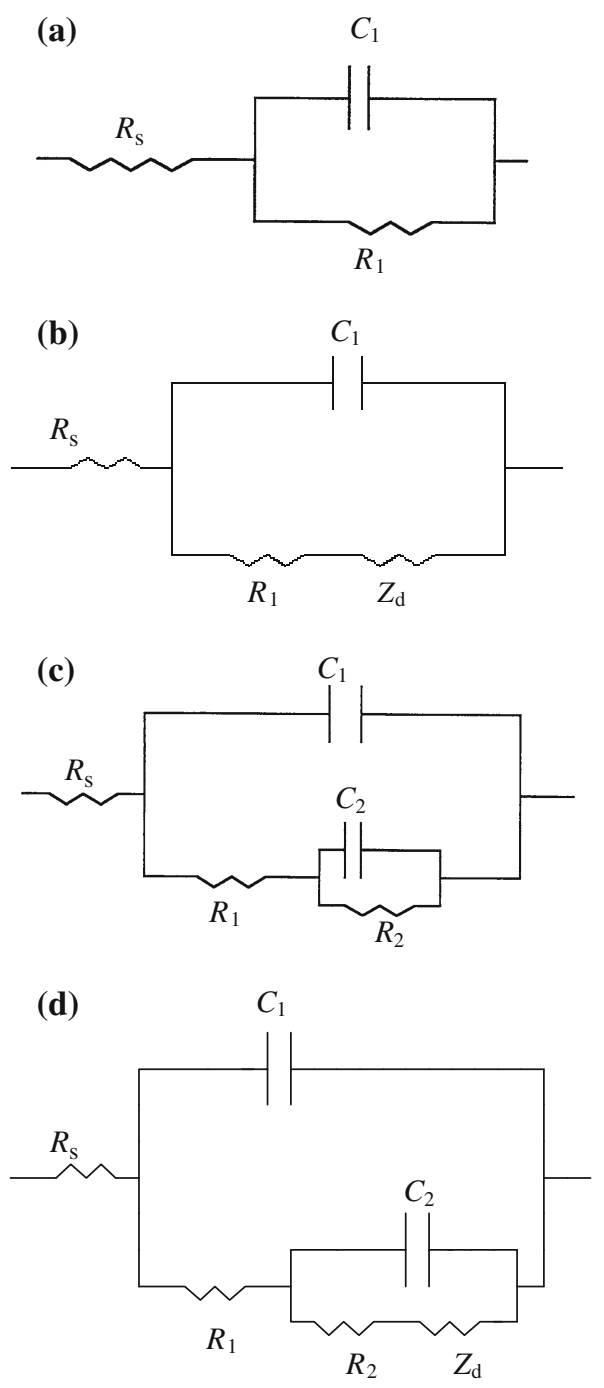

Fig. 1: Equivalent circuits to interpret the response of the steel/organic coating interface in EIS: (a) intact coating, (b) a coating with a diffusion process across it, (c, d) a coating where the faradaic process associated with corrosion started

procedure. It is important to remark that $R_{2}$ and $C_{2}$ values vary inversely and directly, respectively, and with the size of the attacked metallic area. There is almost a unanimous opinion that a polymer-coated metal is represented by the circuit in Fig. 1(c) when water penetrates the coating and reaches the metal. It is also agreed that the general impedance may include the $Z_{\mathrm{d}}$, the mass transfer (Warburg) impedance $^{63}$; Fig 1(b) and (d).

Distortions observed in these resistive-capacitive contributions indicate a deviation from the theoretical models due to either lateral penetration of the electrolyte at the steel/paint interface (usually started at the base of intrinsic or artificial coating defects), underlying steel surface heterogeneity (topological, chemical composition, and surface energy), and/or 
diffusional processes that could take place along the test. $^{78,79}$ Since all these factors cause the impedance/ frequency relationship to be non-linear, they are taken into consideration by replacing the capacitive components $\left(C_{\mathrm{i}}\right)$ of the equivalent circuit transfer function by the corresponding constant phase element $Q_{\mathrm{i}}(\mathrm{CPE})$, thus obtaining a better fit of data. ${ }^{61,63}$ The CPE is defined by the following equation ${ }^{80}$ :

$Z=\frac{(j \omega)^{-n}}{Y_{0}}$

where $Z$ is the impedance of the $\operatorname{CPE}\left(\mathrm{Z}=\mathrm{Z}^{\prime}+Z^{\prime \prime}\right)$ $(\Omega), j$ is the imaginary number $\left(j^{2}=-1\right), \omega$ is the angular frequency $(\mathrm{rad}), n$ is the CPE power $(n=\alpha /(\pi)$ 2) (dimensionless), $\alpha$ is the constant phase angle of the CPE (rad), and $Y_{0}$ is the part of the CPE independent of the frequency $\left(\mathrm{s}^{\alpha} \Omega^{-1}\right)$.

The accuracy of the fitting procedure was measured by the $\chi^{2}$ parameter obtained from the difference between experimental and fitted data; the most probable circuit was selected providing that $\chi^{2}<10^{-4}$. In the present work, the fitting process was mainly performed using the phase constant element $Q_{\mathrm{i}}$ instead of the dielectric capacitance $C_{\mathrm{i}}$.

\section{Electrochemical tests}

The corrosion potential $\left(E_{\text {corr }}\right)$ evolution of coated steel panels immersed in $3 \% \mathrm{NaCl}$ solution is shown in Fig. 2. Differences between these paints became visible from the beginning of the test. $E_{\text {corr }}$ values of panels coated with paints 1 and 3 were displaced to more positive values, indicating that good protection with these paints was achieved during, at least, 9 months. Paint 2 failed from early days showing an $E_{\text {corr }}$ close to that presented by bare steel in similar exposure conditions. Hence, it could be concluded that sodium

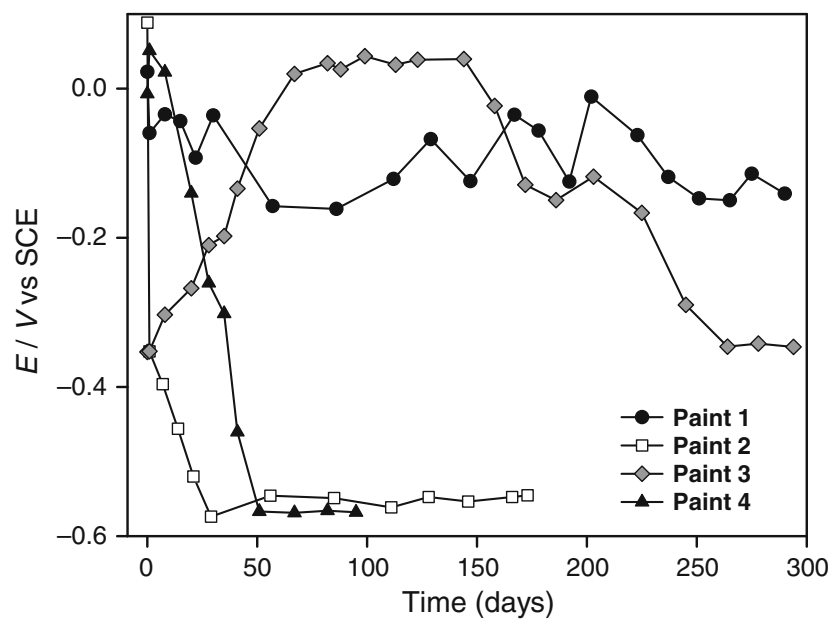

Fig. 2: Corrosion potential of coated steel immersed in $3 \%$ $\mathrm{NaCl}$ solution benzoate did not provide an additional inhibitive effect to this paint. Paint 2 behaved as paint 4, which formulated with a low phosphate content, provided a poor anticorrosive performance. ${ }^{6,23-26}$

In view of these results, it is believed that phosphate and polyphosphate anions, offered a satisfactory anticorrosive action due to the initial passivation of the steel substrate while the phosphate pigment (e.g., zinc phosphate) provided protection in the long term. These results were confirmed by means of EIS measurements.

The analysis of Bode's revealed that paint 1 had a high impedance throughout the entire test period. The values assumed by the phase angle revealed the existence of a resistive-capacitive behavior (Fig. 3). In change, paint 2 showed an initial impedance value higher than $10^{7} \Omega \mathrm{cm}^{2}$ which decreased several order of magnitude after 1 day of immersion (Fig. 4), thus indicating the absence of an effective anticorrosive protection. As in the case of paint 1, water reached the metal substrate from the beginning of the test period and at least two time constants were perceivable. The impedance of paint 3 was very high for 51 days of immersion but it descended although its value ranged $10^{6}-10^{7} \Omega$ for a long period of time. The phase angle showed a similar behavior to the previous cases (Fig. 5). Finally, paint 4, containing only $10 \%$ of zinc phosphate, showed a slightly better behavior than paint 2 but the protective properties were impaired as time elapsed and after 67 days they were practically lost (Fig. 6).

After the examination of Bode's plots, the fitting procedure was carried out to determine the time constants involved in the coatings degradation process. As no pure capacitive behavior was observed in any case, the circuit employed to fit experimental data was that of Fig. 1(c). The exponent " $n$ " in Eq. (1) was comprised between 0.5 and 0.8 , so it was concluded that a CPE $\left(Q_{\mathrm{i}}\right)$ could describe appropriately the dielectric properties of the film and the capacitance of the double layer.

It is reported in the literature that an acceptable barrier effect is attained when $R_{1}>10^{8} \Omega \mathrm{cm}^{2}$, and a residual protective effect is still present if $R_{1}$ ranged between $10^{6}$ and $10^{7} \Omega \mathrm{cm}^{2}{ }^{66,81-83}$ As it can be seen in Fig. 7 , with the exception of paint 2 , the others showed a high barrier effect $\left(R_{1} \sim 10^{8}-10^{9} \Omega \mathrm{cm}^{2}\right)$ which was maintained for paint 1 , but was lost after a few days of immersion in the case of paint 3 and 4 . However, paint 3 conserved a residual barrier effect $\left(R_{1}>10^{6} \Omega \mathrm{cm}^{2}\right)$ during all the test period and paint 4 lost its barrier properties after 50 days of immersion. The oscillating behavior observed for paints 1 and 3 was attributed to pore blocking with corrosion products which, temporarily, enhance the steel protection. On the other hand, the dielectric properties of paints 1 and $3\left(Q_{1} \sim 10^{-8}-10^{-9} \mathrm{~F} \mathrm{~cm}^{-2}\right)$ corresponded to nondamaged films. ${ }^{66,82,83}$ Again, the poorer behavior was obtained when sodium benzoate was employed as additive, since the values of $Q_{1}, \sim 10^{-6} \mathrm{~F} \mathrm{~cm}^{-2}$, similar 

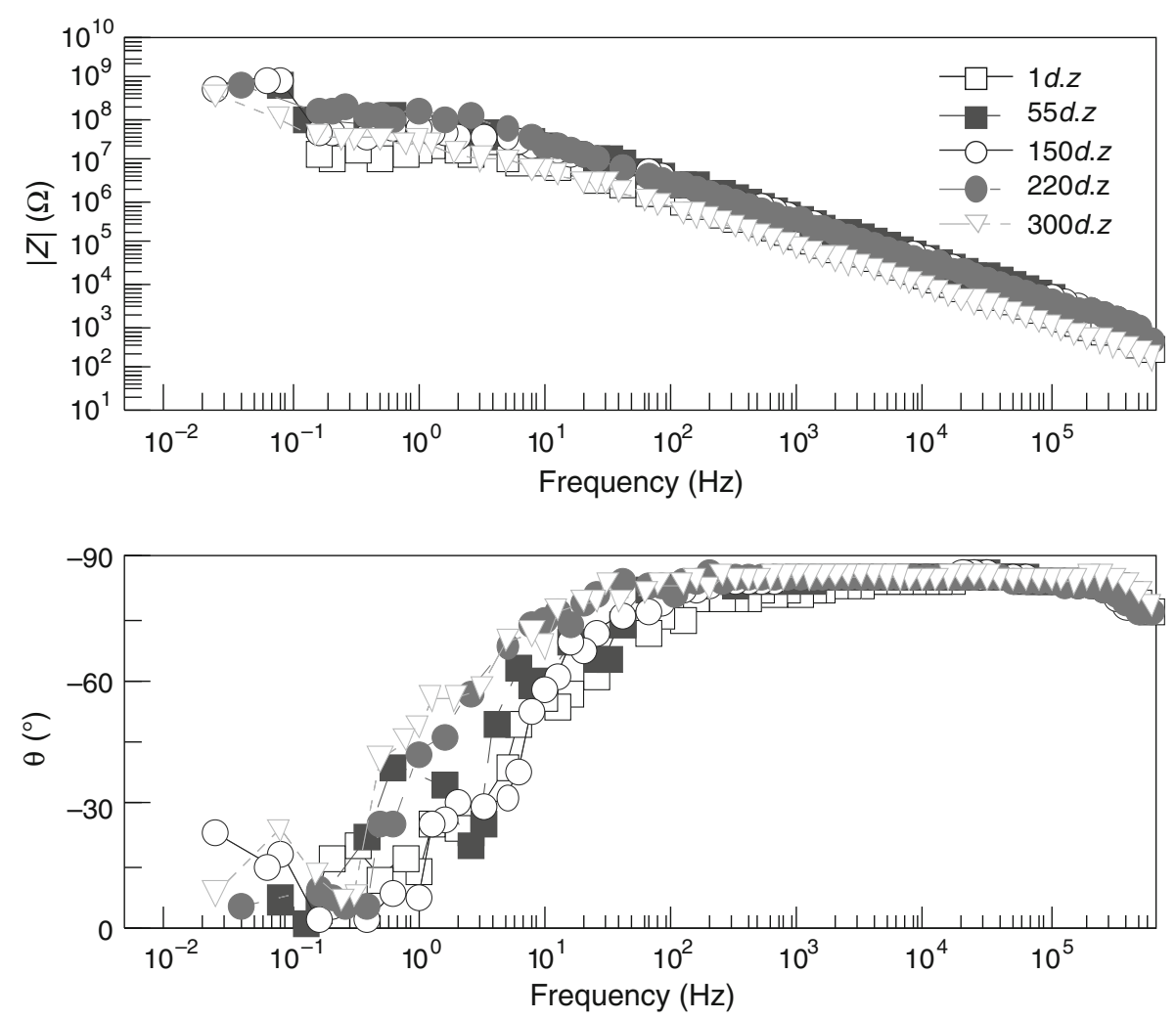

Fig. 3: Bode plots for paint 1 immersed in $3 \% \mathrm{NaCl}$ solution
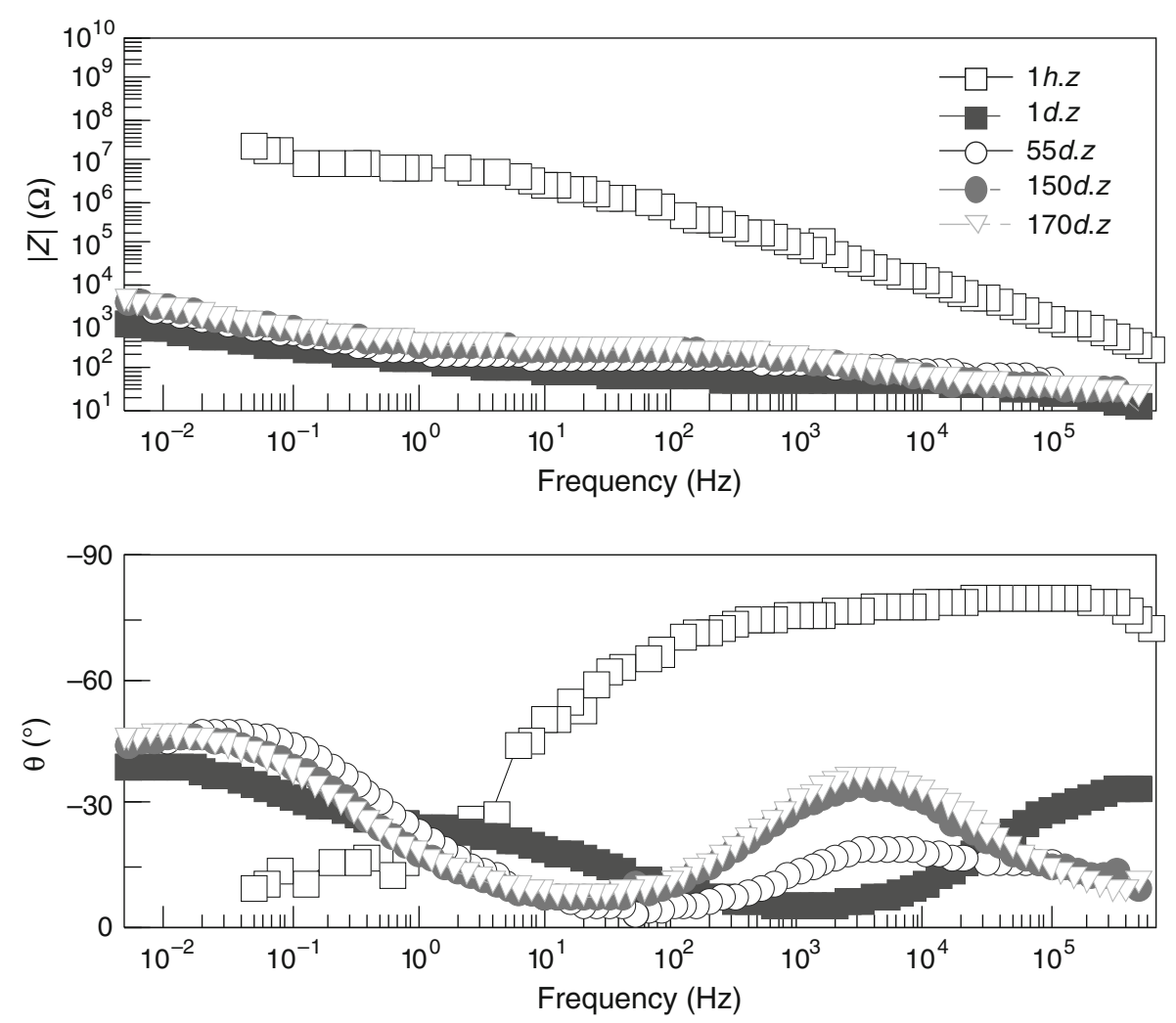

Fig. 4: Bode plots for paint 2 immersed in $3 \% \mathrm{NaCl}$ solution 

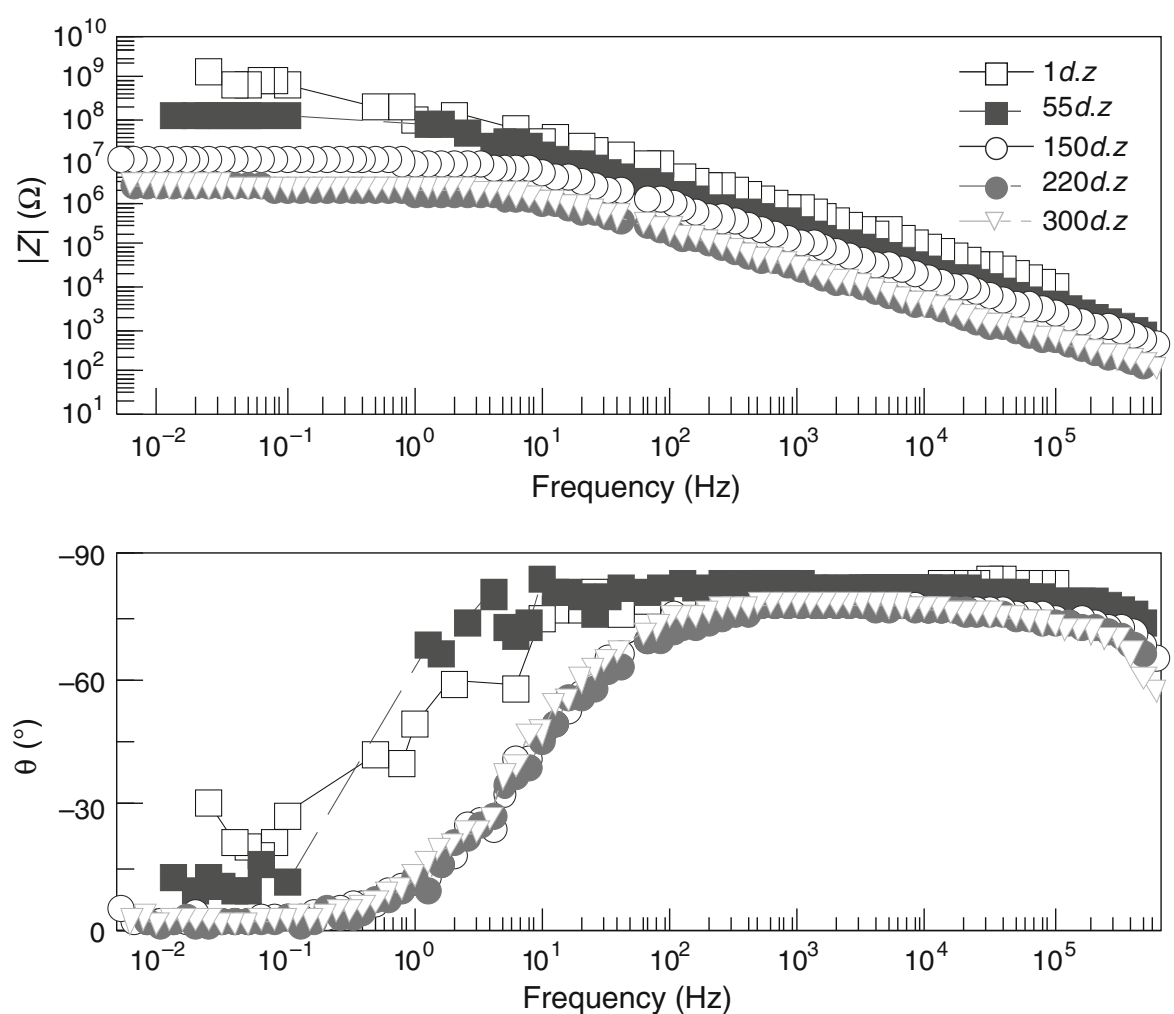

Fig. 5: Bode plots for paint 3 immersed in $3 \% \mathrm{NaCl}$ solution
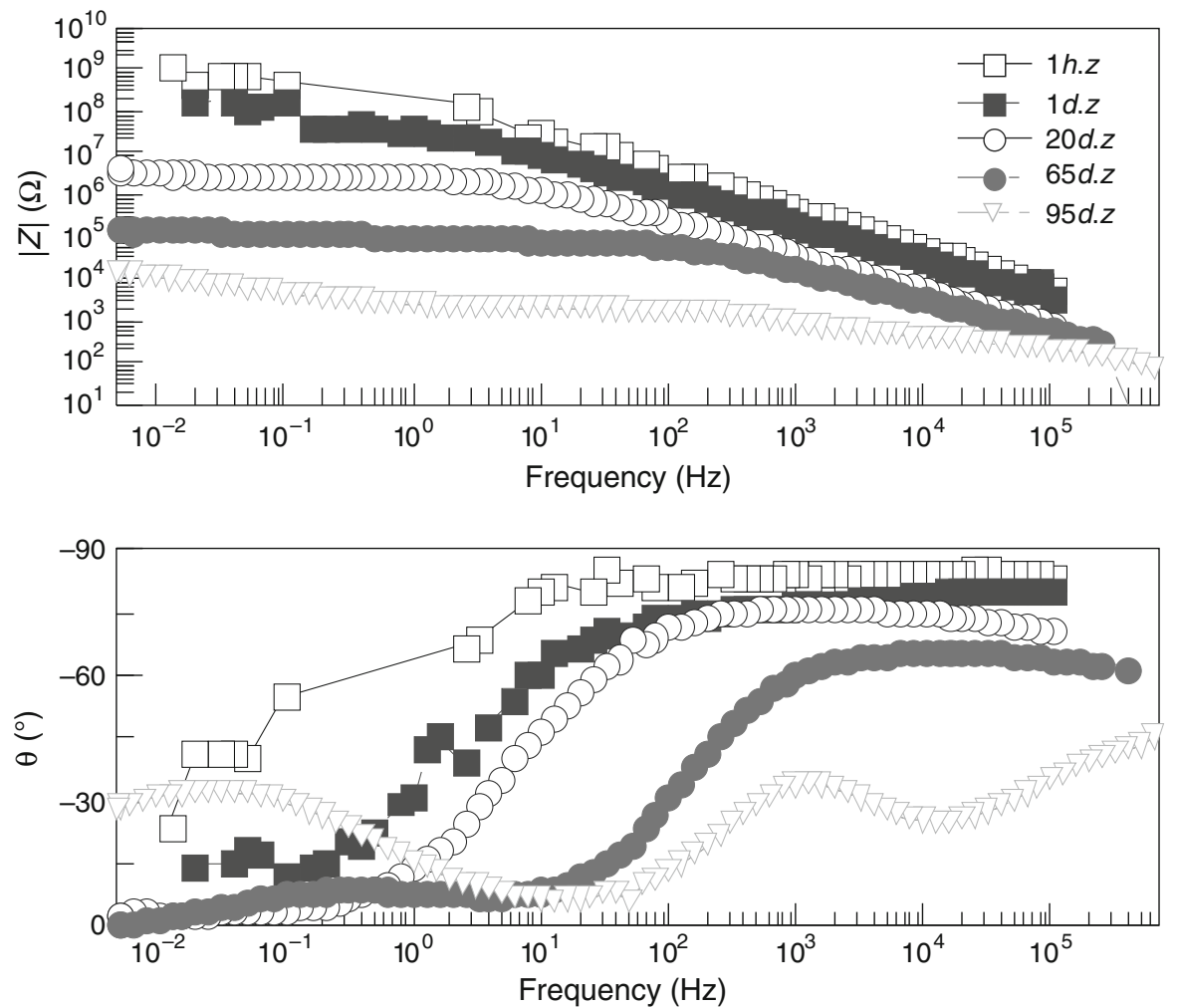

Fig. 6: Bode plots for paint 4 immersed in $3 \% \mathrm{NaCl}$ solution 


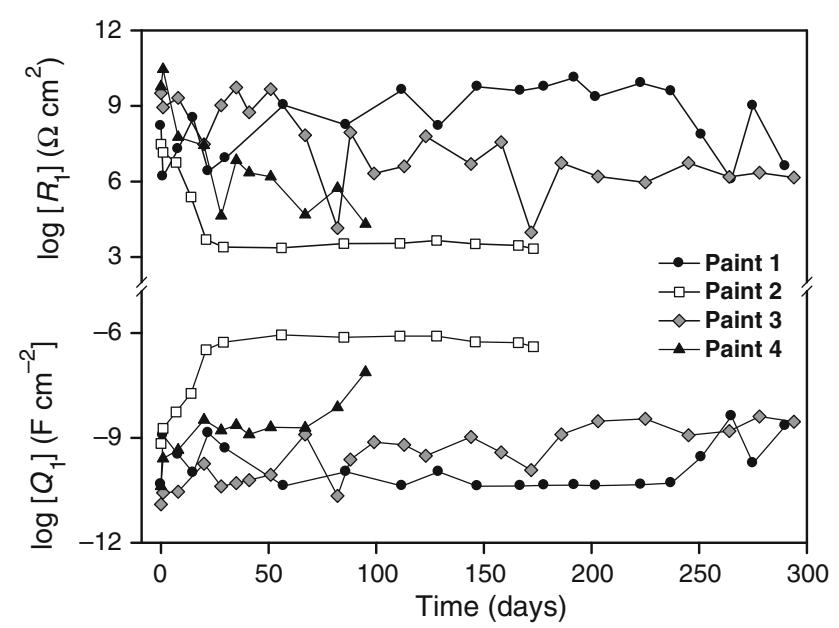

Fig. 7: Fitting parameters $\left(R_{1}\right.$ and $\left.Q_{1}\right)$ of coated steel immersed in $3 \% \mathrm{NaCl}$ solution

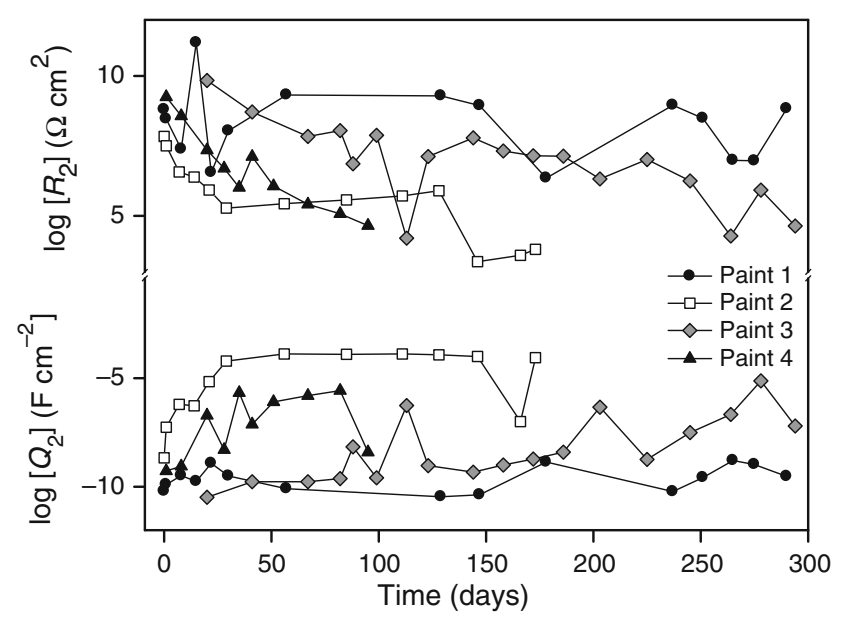

Fig. 8: Fitting parameters $\left(R_{2}\right.$ and $\left.Q_{2}\right)$ of coated steel immersed in $3 \% \mathrm{NaCl}$ solution

to the electrochemical double-layer capacitance of bare steel, are indicative of a total loss of paint barrier properties and delamination at the steel/paint film interface.

As can be seen in Fig. 8, the parameters associated with the faradaic process, $R_{2}-Q_{2}$, showed an important inhibition of the corrosion process in the case of paints 1 and 3. It is perceptible that $R_{2}$ ranged between $10^{7}$ to $10^{10} \Omega \mathrm{cm}^{2}$ for these paints during, approximately, all the test period. This fact was attributed to the existence of an almost negligible electrochemical active area due to the initial steel passivation provided for the soluble phosphate species combined with the less important but also effective barrier effect afforded by the paint. The charge transfer resistance of paints 2 and 4 was some orders of magnitude lower than that of the above-mentioned paints, revealing a significant progress of the corrosion process which, in turn, was originated by the low phosphate content and the poor anticorrosive behavior of sodium benzoate.

The capacitance of the electrochemical double layer $\left(Q_{2}\right)$, coupled to the charge transfer resistance $\left(R_{2}\right)$, remained between $10^{-8}$ and $10^{-10} \mathrm{~F} \mathrm{~cm}^{-2}$ for paints 1 and 3; such a behavior confirmed the assumptions made to interpret $R_{2}$ (Fig. 8). On the contrary, the rest of the painted samples showed rather low $Q_{2}$ values after few days of immersion due to the progress of corrosion process associated with a large electrochemically active area.

The oscillating behavior of $R_{2}-Q_{2}$ values could be attributed to dynamic changes in the surface covering degree with a protective layer of corrosion products.

\section{Conclusions}

1. Soluble anticorrosive additives could improve paints anticorrosive performance if they are selected adequately.

2. Sodium phosphate and sodium polyphosphate could improve the anticorrosive performance of alkyd paint formulations with reduced zinc phosphate contents.

3. The electrochemical response of painted panels indicated that initial steel passivation was achieved when suitable additives were employed in combination with zinc phosphate.

4. There was good correlation between salt spray tests, corrosion potential measurements, and EIS test.

5. The most interesting feature is that soluble additives allowed for the reduction of the zinc phosphate content in anticorrosive paints to a third of the recommended value without diminishing paint performance. As a consequence, more cost-effective paints could be formulated with less environmental impact.

Acknowledgments We thank to CONICET (Consejo Nacional de Investigaciones Científicas y Técnicas), CICPBA (Comisión de Investigaciones Científicas de la Provincia de Buenos Aires), and UNLP (Universidad Nacional de La Plata) for their sponsorship to do this research.

\section{References}

1. Romagnoli, R, Vetere, VF, "Heterogeneous Reaction Between Steel and Zinc Phosphate." Corrosion (NACE), 51 116-123 (1995)

2. Szklarska-Smialowska, Z, Mankowsky, J, "Cathodic Inhibition of the Corrosion of Mild Steel in Phosphate, Tungstate, Arsenate and Silicate Solutions Containing $\mathrm{Ca}^{2+}$ Ions." $\mathrm{Br}$. Corr. J., 4 271-275 (1969) 
3. Meyer, G, "Moderne weiße Inibitorpigmente und deren Kombinationen in Anstrichsystemen." Farbe + Lack, 71 (2) 113-118 (1965)

4. Barraclouugh, J, Harrison, JB, "New Leadless AntiCorrosive Primers." J. Oil Col. Chem. Assoc., 48 (4) 341-355 (1965)

5. Fragata, F de L, Dopico, JE, "Anticorrosive Behavior of Zinc Phosphate in Alkyd and Epoxy Binders." J. Oil Col. Chem. Assoc., 74 (3) 92-97 (1991)

6. Romagnoli, R, Vetere, VF, "Non Pollutant Corrosion Inhibitive Pigments: Zinc Phosphate, a Review." Corros. Rev., 13 (81) 45-64 (1995)

7. Svoboda, M, Mleziva, J, "Properties of Coatings Determined by Anticorrosive Pigments." Prog. Org. Coat., 12 251-297 (1984)

8. Chromy, L, Kaminska, E, "Non-Toxic Anticorrosive Pigments." Prog. Org. Coat., 18 319-324 (1990)

9. Gerhard, A, Bittner, A, "Second Generation Phosphate Anti-Corrosive Pigments. Formulating Rules for Full Replacement of New Anti-Corrosive Pigments." J. Coat. Technol., 58 59-65 (1986)

10. Bittner, A, "Advanced Phosphate Anticorrosive Pigments for Compliant Primers.' J. Coat. Technol., 61 114-118 (1989)

11. Romagnoli, R, del Amo, B, Vetere, VF, Vèleva, L, "High Performance Anticorrosive Epoxy Paints Pigmented with Zinc Molybdenum Phosphate." Surf. Coat. Int., 83 27-31 (2000)

12. del Amo, B, Romagnoli, R, Vetere, VF, "Study of the Anticorrosive Properties of Zinc Phosphate and Zinc Molybdophosphate in Alkyd Paints." Corros. Rev., 14 121-133 (1996)

13. Vetere, VF, Romagnoli, R, "Role of Calcium Acid Phosphate as Corrosion Inhibitive Pigment." Br. Corr. J., 29 115-119 (1994)

14. del Amo, B, Romagnoli, R, Vetere, VF, "Steel Corrosion Protection by Means of Alkyd Paints Pigmented with Calcium Acid Phosphate." Ind. Eng. Chem. Res., 38 2310-2314 (1999)

15. Taketani, Y, Kondo, H, Kropman, M, "Propertary Aluminum Triphosphate Pigments for Waterborne Coatings." Polym. Paint Col. J., 183 270-271 (1993)

16. Jackson, KG, Kropman, M, "Novel Waterborne High Performance Steel Primer." Polym. Paint Col. J., 178 559-561 (1988)

17. Takahashi, M, "Characteristics and Applications of Aluminium Triphosphate as Special Chemical." Polym. Paint Col. J., 174 281-284 (1984)

18. Kamiya, K, Okuda, M, Okajima, M, "Combination Effect of K-White and Chromate Pigments in Coil Coatings Systems." Polym. Paint Col. J., 178 974-980 (1988)

19. Nakano, J, Murakami, M, Okuda, M, "Aluminium Triphosphate-Salt Spray Studies.” Polym. Paint Col. J., 177 642-645 (1987)

20. Nishihara, M, Nakano, G, Kobayashi, M, Nagita, M, Murakami, M, "Studies on Anticorrosive Properties of Aluminium Triphosphate Pigments. Corrosion Inhibitive Properties in Alkyd Resin Coatings System." Polym. Paint Col. J., 174 590-597 (1984)

21. Noguchi, T, Nahono, J, Kabayashi, M, Nagita, M, Kinugasa, M, Murakami, M, "Studies on Anticorrosive Properties of Aluminium Triphosphate Pigments. Corrosion Inhibitors Properties in Epoxy Resin Coatings System." Polym. Paint Col. J., 174 888-891 (1984)

22. Deyá, M, Vetere, V, Romagnoli, R, del Amo, B, "Aluminium Tripolyphosphate Pigments for Anticorrosive Paints." Pigment Resin Technol., 30 13-24 (2001)
23. Vetere, V, Deyá, M, Romagnoli, R, del Amo, B, "Calcium Tripolyphosphate: An Anticorrosive Pigment for Paints." J. Coat. Technol., 73 57-63 (2001)

24. Deyá, M, Blustein, G, Romagnoli, R, del Amo, B, "The Influence of the Anion Type on the Anticorrosive Behaviour of Inorganic Phosphates." Surf. Coat. Technol., 150 133-142 (2002)

25. Deyá, M, Vetere, VF, Romagnoli, R, Del Amo, B, "Zinc Tripolyphosphate: An Anticorrosive Pigment for Paints." Surf. Coat. Int., 86 B 79-85 (2003)

26. Pryor, MJ, Cohen, M, "The Inhibition of the Corrosion of Iron by Some Anodic Inhibitors." J. Electrochem. Soc., 100 203-215 (1953)

27. Blustein, G, del Amo, B, Romagnoli, R, "The Influence of the Solubility of Zinc Phosphate Pigments on their Anticorrosive Behaviour." Pigment Resin Technol., 29 100-107 (2000)

28. Deyá, MC, Blustein, G, Romagnoli, R, del Amo, B, "Zinc Phypophosphite: A Suitable Additive for Anticorrosive Paints to Promote Pigments Synergism." J. Coat. Technol. Res., 6 (3) 369-376 (2009)

29. Hodges, SA, Uphues, WM, Tran, MT, "Non-Toxic Corrosion Inhibitive Synergistic System." Surf. Coat. Int., 80 178-183 (1997)

30. Kalendová, A, Veselý, D, Stejskal, J, “Organic Coatings Containing Polyaniline and Inorganic Pigments as Corrosion Inhibitors." Prog. Org. Coat., 62 105-116 (2008)

31. Deyá, C, Romagnoli, R, del Amo, B, "A New Pigment for Smart Anticorrosive Coatings." J. Coat. Technol. Res., 4 167-175 (2007)

32. Aramaki, K, Hagiwara, M, Nishihara, H, “The Synergistic Effect of Anions and the Ammonium Cation on the Inhibition of Iron Corrosion in Acid Solution." Corr. Sci., 27 (5) 487-497 (1987)

33. Robu, C, Orban, N, Varga, G, “Anticorrosive Lead Free Pigments Combination." Polym. Paint Col. J., 177 566-569 (1987)

34. Rozados, E, Vetere, V, Carbonari, R, "Estúdio sobre inhibidores inorgânicos: efecto de mezclas de cromatofosfto." Corr. Prot., 9 (3-4) 3-10 (1978)

35. Meyer, E, "Uber Zinkphosphat und Bariumchromat als moderne Korrosionsinhibitoren." Farbe + Lack, 7 528-532 (1963)

36. Johnson, W, "Cost Effective Pigmentation in Alkyd Primers for Steel: Barrier Anticorrosion Mechanism." J. Coat. Technol., 66 (831) 47-54 (1994)

37. Jabeera, B, Shibli, S, Anirudhan, T, "The Synergistic Effect of Molybdte with Zinc for the Effective Inhibition of Corrosion of Mild Steel." Corr. Prev. Control, pp. 65-70, June 2001

38. Kumari, A, Sreevalsan, K, Shibli, S, "Sodium Molibdatye for the Effective Protection of Steel: A Comprehensive Review." Corr. Prev. Control, pp. 83-96, September 2001

39. Simpson, $\mathrm{CH}$, “US Navy Develops Non-toxic, Self Priming Coatings for Aluminium and Steel." Paint Coat. Ind., June 1993

40. Jackson, MA, "Guidelines to Formulation to Water-borne Epoxy Primers: An Evaluation of Anti-Corrosive Pigments." J. Prot. Coat. Linings, 7 (4) 54-64 (1990)

41. Technical Data Sheet, Halox ${ }^{\circledR}$ Flash-X330 Halox Flash Rust Inhibitors

42. Morcillo, M, Rodríguez, FJ, Bastidas, JM, “The Influence of Chlorides, Sulphates and Nitrates at the Coating-Steel Interface on Underfilm Corrosion." Prog. Org. Coat., 31 245-253 (1997) 
43. Morcillo, M, "Soluble Salts: Their Effect on Premature Degradation of Anticorrosive Paints." Prog. Org. Coat., 36 137-147 (1999)

44. de la Fuente, D, Bohm, M, Houyoux, C, Rohwerder, M, Morcillo, M, "The Settling of Critical Levels of Soluble Salts for Painting." Prog. Org. Coat., 58 23-32 (2007)

45. Eurof Davies, D, Slaiman, QJM, "Mechanism of the Corrosion Inhibition of Fe by Sodium Benzoate-I. The Influence of Concentration and $\mathrm{pH}$ in Air-Saturated Solutions of Sodium Benzoate." Corr. Sci., 11 671-682 (1971)

46. Slaiman, QJM, Eurof Davies, D, "Mechanism of the Corrosion Inhibition of Fe by Sodium Benzoate-II. The Inhibitive Properties of Sodium Benzoate in De-aerated and AirSaturated Solution." Corr. Sci., 11 683-692 (1971)

47. Blustein, G, Zinola, CF, "Inhibition of Steel Corrosion by Calcium Benzoate Adsorption in Nitrate Solutions; Theoretical and Experimental Approach." J. Colloid Interface Sci., 278 393-403 (2004)

48. Eurof Davies, D, Slaiman, QJM, "Mechanism of the Corrosion Inhibition of Fe by Sodium Benzoate-III. The Role of Oxygen." Corr.Sci., 13 891-905 (1973)

49. Muralidharan, VS, Sethuraman, R, Krishnamoorthy, S, "Benzoic Acid as Corrosion Inhibitors for Pure Iron in Sulphuric Acid." Bull. Electrochem., 4 705-710 (1988)

50. Argawal, P, Landolt, D, "Effect of Anions on the Efficiency of Aromatic Carboxylic Acid Corrosion Inhibitors in Near Neutral Media: Experimental Investigation and Theoretical Modeling." Corr. Sci., 4 (5) 673-691 (1998)

51. Kahraman, R, "Inhibition of Atmospheric Corrosion of Mild Steel by Sodium Benzoate Treatment." J. Mater. Eng. Perform., 11 46-50 (2002)

52. Takahashi, K, Bardwell, JA, Mac Dougall, B, Graham, MJ, "Mechanism of Anodic Dissolution and Passivation of IronII. Comparison of the Behavior in Neutral Benzoate and Acetate Buffer Solutions." Electrochimi. Acta, 37 489-494 (1992)

53. Blustein, G, Rodríguez, J, Zinola, CF, Romagnoli, R, "Inhibition of Steel Corrosion by Calcium Benzoate Adsorption in Nitrate Solution." Corr. Sci., 47 369-383 (2005)

54. Blustein, G, "Metallic Benzoates as Anticorrosive Pigments, Synthesis and Characterization." In: Development of Metallic Benzoates Based Inhibitors for Steel Anticorrosive Protection, Chapter 3. Thesis defended at the National University of La Plata, La Plata, Argentina, 2005

55. Blustein, G, Romagnoli, R, Jaén, JA, Di Sarli, AR, del Amo, B, "Zinc Basic Benzoate as Eco-Friendly Steel Corrosion Inhibitor Pigment for Anticorrosive Epoxy-Coatings." Colloids Surf. A Physicochem. Eng. Asp., 290 7-18 (2006)

56. Blustein, G, Di Sarli, AR, Jaén, JA, Romagnoli, R, del Amo, B, "Study of Iron Benzoate as a Novel Steel Corrosion Inhibitor Pigment for Protective Paint Films." Corr. Sci., 49 4202-4231 (2007)

57. Blustein, G, Romagnoli, R, Jaén, JA, Di Sarli, AR, del Amo, B, "Aluminum Basic Benzoate-Based Coatings: Evaluation of Anticorrosion Properties by Electrochemical Impedance Spectroscopy and Accelerated Tests." Corrosion (NACE), 63 (10) 899-915 (2007)

58. ASTM B 117. American Society for Testing and Materials, 1992 Annual Book of ASTM Standards, Section 6, Standard Method of Salt Spray (Fog) Testing, Paint-Tests for Formulated Products and Applied Coatings, vol. 06.01, 1992, p. 1. Easton, MD, 1990

59. ASTM D 610-95. American Society for Testing and Materials, 1996 Annual Book of Standards, Section 6, PaintProducts and Applications; Protective Coatings; Pipeline Coatings: Standard Test Method for Evaluating Degree of
Rusting on Painted Steel Surfaces, vol. 06.02, 1996, p. 13. Easton, MD, 1995

60. ASTM D 714-87. American Society for Testing and Materials, 1996 Annual Book of Standards, Section 6, Paint-Tests for Chemical, Physical and Optical Properties; Appearance: Standard Test Method for Evaluating Degree of Blistering of Paints, vol. 06.01, 1996, p. 62. Easton, MD, 1987

61. Boukamp BA, Report CT88/265/128, CT89/214/128, University of Twente. The Netherlands, 1989

62. del Amo, B, Romagnoli, R, Vetere, VF, Hernández, LS, "Study of the Anticorrosive Properties of Zinc Phosphate in Vinyl Paints." Prog. Org. Coat., 33 28-35 (1998)

63. Amirudin, A, Thierry, D, "Application of Electrochemical Impedance Spectroscopy to Study Efficiency of Anticorrosive Pigments in Epoxy-Polyamide Resin." Br. Corr. J., 30 128-134 (1995)

64. Mansfeld, F, "Recording and Analysis of AC Impedance Data for Corrosion Studies. Background and Methods of Analysis." Corrosion (NACE), 36 (5) 301-307 (1981)

65. Kendig, M, Scully, J, "Basic Aspects of Electrochemical Impedance. Application for the Life Prediction of Organic Coatings on Metals." Corrosion, 46 (1) 22-29 (1990)

66. Szauer, T, "Impedance Measurements for the Evaluation of Protective Nonmetallic Coatings." Prog. Org. Coat., 10 171-183 (1982)

67. Miszczyk, A, Szalinska, H, "Laboratory Evaluation of Epoxy Coatings with an Adhesion Promoter by Impedance." Prog. Org. Coat., 25 357-363 (1995)

68. Ferraz, O, Cavalcanti, E, Di Sarli, AR, "The Characterization of Protective Properties for Some Naval Steel/Polymeric Coatings $/ 3 \% \mathrm{NaCl}$ Solution Systems by EIS and Visual Assessment." Corros. Sci., 37 (8) 1267-1280 (1995)

69. Seré, PR, Santágata, DM, Elsner, CI, Di Sarli, AR, "The Influence of the Method of Application of Paint on the Corrosion of the Substrate as Assessed by ASTM and Electrochemical Methods." Surf. Coat. Int., 3 128-134 (1998)

70. Santágata, DM, Seré, PR, Elsner, CI, Di Sarli, AR, "Evaluation of the Surface Treatment Effect on the Corrosion Performance of Paint Coated Carbon Steel." Prog. Org. Coat., 33 44-54 (1998)

71. Armas, AR, Seré, PR, Elsner, CI, Di Sarli, AR, "The Surface Condition Effect on Adhesion and Corrosion Resistance of Carbon Steel/Chlorinated Rubber/Artificial Sea Water Systems." Corr. Sci, 38 (6) 853-866 (1996)

72. Brasher, D, Nurse, TJ, "Electrical Measurements of Immersed Paint Coatings on Metal. II. Effect of Osmotic Pressure and Ionic Concentration of Solution on Paint Breakdown." J. Appl. Chem., 9 96-106 (1959)

73. Leidheiser, HJR, Kendig, MW, "Mechanism of Corrosion of Polybutadiene-Coated Steel in Aerated Sodium Chloride." Corrosion, 32 69-76 (1976)

74. Kendig, MW, Leidheiser, H, "Electrical Properties of Protective Polymer Coatings as Related to Corrosion of the Substrate." J. Electrochem. Soc, 123 (7) 982-989 (1980)

75. Mansfeld, F, Kendig, M, "Electrochemical Impedance Tests for Protective Coatings." In: Haynes, C, Baboian, R (eds.) ASTM Publication STP 866, pp. 122-142. ASTM, Philadelphia, PA, 1985

76. Beaunier, L, Epelboin, I, Lestrade, JC, Takenouti, H, "Etude electrochimique, et par microscopie electronique a balayage, du fer recouvert de peinture." Surf. Technol., 3 237-254 (1976)

77. Gabrielli, G, Keddam, M, Mattos, OR, Takenouti, H, "Charge Transfer Resistance Measurements by Galvanostatic Double Pulse and Impedance Methods." J. Electroanal. Chem., 117 147-153 (1981) 
78. Szauer, T, Brandt, A, "Impedance Measurement on ZincRich Paints." J. Oil Col. Chem. Assoc., 67 13-15 (1984)

79. Frydrych, DJ, Farrington, GC, Townsend, HE, In: de Kendig, MW, Leidheiser, H, Jr (eds.) Corrosion Protection by Organic Coatings, Vol. 87(2), p. 240. The Electrochem. Soc., Pennington, NJ, 1987

80. van Westing, EPM, Ferrari, GM, Geenen, FM, van de Wit, JHW, "In situ Determination of the Loss of Adhesion of Barrier Epoxy Coatings using Electrochemical Impedance Spectroscopy." Prog. Org. Coat., 23 89-103 (1993)
81. Standish, JV, Leidheiser, H, Jr, "The Effect of Water on the Dielectric Properties of a Corrosion-Protective Epoxy Polyamide Coating." Org. Coat. Plast. Chem., 43 565-569 (1980)

82. Elsner, CI, Di Sarli, AR, "Comparison Between Electrochemical Impedance and Salt Spray Test in Evaluating the Effect of Epolxy Paints." Braz. Chem. Soc., 51 15-18 (1994)

83. Leidheiser, H, "Electrical and Electrochemical Measurements as Predictors of Corrosion at the Metal-Organic Coating Interface." Prog. Org. Coat., 7 79-104 (1979) 